\title{
The Transition from Corporate Careers to Business Ownership: The Case for Women Entrepreneurs in Malaysia
}

\author{
Siri Roland Xavier \\ University Tun Abdul Razak \\ xsroland@gmail.com \\ Syed Zamberi Ahmad \\ Prince Sultan University, Riyadh, Kingdom of Saudi Arabia \\ drszamberi@yahoo.com \\ Suganthi Perumal \\ University Tun Abdul Razak, Kuala Lumpur, Malaysia \\ Leilanie Mohd Nor \\ University Tun Abdul Razak, Kuala Lumpur, Malaysia \\ Jagadesan Chandra Mohan (Corresponding author) \\ University Tun Abdul Razak, Kuala Lumpur, Malaysia \\ jagadesancm@hotmail.com
}

Received: June 2, 2011 Accepted: July 14, 2011 doi:10.5430/ijba.v2n3p148

\begin{abstract}
This study aimed to explore some features regarding corporate women and their involvement in entrepreneurship. The questions explored were (1) What are the factors that spur women leaving the corporate world into business ownership; (2) What are their personal and entrepreneurial characteristics and (3) What are the challenges and problems they are facing? The study used a convenience sample comprising 51 women entrepreneurs. A self administered questionnaire was distributed by email and via fax. As for the findings, the main factors identified to have spurred women leaving the corporate world into business ownership were needed to achieve personal growth, independence and economic payoff. Passion for the business, listening and communication skills and self discipline are among the most possessed personal skills. The prime entrepreneurial skills that were indicated strongly include showing confidence, leadership skills, creative thinking in problem solving, being efficient and effective in executing plans, entrepreneurial/business knowledge, being analytical, balancing skills between personal and business life, and flexibility i.e. ability to change. The challenges /problems faced by the respondents are shortage of professional staffs, shortage of staffs, issues of development and growth, financial constraint due to heavy overheads and less consultation help from experts. There were no significant differences were found in most of entrepreneurial characteristics among the major ethnic groups. The study recommends further research that may capture more and richer aspects of women's entrepreneurship.
\end{abstract}

Keywords: Women Entrepreneurs, Business Ownership and Entrepreneurial Characteristics.

\section{Introduction}

\subsection{Background of the Study}

Many women are saying goodbye to the corporate work in favor of creating their own through entrepreneurship It is not an uncommon trend that the number of women entrepreneurs continues to increase steadily worldwide. Women represent more than one-third of all people involved in entrepreneurial activity [Global Entrepreneurship Monitor (GEM), 2004]. In Malaysia, the Companies Commission of Malaysia (CCM, 2003), reported that 49,554 units of 
women-owned businesses were registered in 2000, and the number has increased to 54,626 units in 2001. A study, by the Asian Institute of Management (April, 1987) of corporate women managers in South East Asia, shows that 62\% of the respondents are senior managers and 38\% are middle managers (Bitange Ndemo, 2007).

\subsection{Statement of Problem}

Why are more and more women leaving the corporate careers for business ownership? There are many reasons why women become entrepreneurs and many barriers and obstacles that they must overcome.

In examining different theories and the reasons why women become entrepreneurs, there is no set and standard profile that can be predictably applied. For every woman who is an entrepreneur or wants to become one, they each have their own set of reasons, motivation, and many cannot be categorized or 'labeled' (Kamal Naser, 2009). Helm (1997) argues in her paper that men and women have different reasons for entering business and that women have "internal-stable reasons ("I want to be my own boss"), while men have external-stable reasons ("I saw a terrific market opportunity”). This study also seeks to identify the entrepreneurial characteristics, the challenges as well as the problems of these women entrepreneurs in Klang Valley, Malaysia.

\subsection{Objectives of the Study}

The purpose of this study is to investigate why women leave their corporate world to become entrepreneurs, in particular, the factors that spur them into business ownership, the challenges and the problems.

Specifically, the objective of the study is to:

(i) Identify the factors that spur the corporate women into business ownership.

(ii) Identify the characteristics of such women entrepreneurs or the "entrepreneurial characteristics” as defined by Gartner (1989).

(iii) Identify the challenges, and problems faced by these women entrepreneurs

\section{Research Questions}

This study attempts to answer the following questions:

(i) What are the factors that spur the corporate women into business ownership?

(ii) What are the entrepreneurial characteristics of such women?

(iii) What are the challenges and problems faced by these women entrepreneurs?

\subsection{Significance of the Study}

This study can provide a list of factors that spur women into their own businesses, and the entrepreneurial characteristics of such women in the Klang valley. The information obtained will serve as guideline in determining the factors and the characteristics more accurately. It also intends to bring to the surface some interesting information about the challenges, and problems. With these findings, it is believed that the study can help deliver a profile of women entrepreneurs to new and aspiring candidates who wish to become entrepreneurs.

\subsection{Factors that spur corporate women into business ownership}

Moore and Buttner (1997) acknowledged that many of the reasons women gave for making the leap to entrepreneurship were also evident in studies of men; however, "other reasons appear special to women". Although there is considerable overlap in motivations and aspirations, the relative importance of the departure influences appears to differ somewhat for women and men. Gender, only occasionally in the form of discrimination, makes a difference". (p.50).

Aminah (1998) in a study of selected successful career women in Malaysia, revealed that changing attitudes of parents and husbands towards a more positive trend were perceived to be related to higher educational attainment of women which in turn could influence women's participation in the management by setting up their own businesses.

\subsection{Entrepreneurial challenges and problems}

In Malaysia, women entrepreneurs faced a shortage of peer support networks compared with men [Women Institute of Management (WIM), 1997. Kim Klyver, 2007, Amzad Hossain, 2009, Julie R, 2009] even though various women entrepreneurs and industry associations have been formed (FEM, NAWEM, USAHANITA) which generally serve as a platform for women entrepreneurs to establish networks and exchange information and experiences as well as to conduct training programmes, seminars and workshops on motivation, leadership and entrepreneur development and to provide other means of support. Women are overloaded with business and family responsibilities and may not have the time to join these beneficial associations. This automatically limits the women entrepreneurs' wings of exploration which are 
essential for survival and business growth. This might pose a challenge to women entrepreneurs in establishing networks which are helpful to the survival of their businesses.

The above are the common challenges faced by women entrepreneurs which produce the following statistic in Malaysia. In 1980, women accounted for only $7 \%$ of employers in the economically active population of Malaysia. In 1984, $0.6 \%$ of Malaysian women entrepreneurs were classified as employers, while $16 \%$ were classified as own-account workers. Hardly $10 \%$ of the total number of all employers was women (Jamilah, 1992). The percentage rose to only $8.5 \%$ in 1990 , with men still comprising the vast majority in employer status [Women's Aid Organisation (WAO), 2001]. The importance of women as an untapped source of entrepreneurship is widely accepted.

A journal was written by Md. Nor Othman, Ezlika Ghazali, Ong Chee Cheng (2004) to investigate whether becoming an entrepreneur is characterised by entrepreneur's personality characteristics. The study concluded that Malays derive satisfaction from working hard and seeing the job well done as compared to the Chinese and that Chinese enjoy having power over people as compared to the Malays.

\section{Research Methodology}

\subsection{Research Design}

A survey method was employed whereby questionnaires were distributed personally to respondents in the Klang Valley-Kuala Lumpur-Petaling Jaya. The respondents were asked to provide responses to items on a five-point Likert scale to measure the strength of their opinion. The research used quantitative method to gather the information regarding key points.

\subsubsection{Population and Sample}

The population of this study includes all women entrepreneurs who have moved from the corporate sectors into business ownership in Klang Valley. The sample for the study comprised 51 such women who participated in the survey.

\subsubsection{Entrepreneur}

Refers to one who reforms or revolutionizes the pattern or production by exploiting an invention, or, more generally, an untried technological possibility for producing a new commodity or producing an old one in a new way, by opening up a new source of supply of materials or new outlet for products, by reorganizing an industry and so on (Schumpeter, 1942, p. 132)

\subsubsection{Women Entrepreneurs}

Refers to women, who have initiated business, actively involved in managing it, own at least $50 \%$ of the firm, and have been in operation one year or longer. (Moore \& Butter, 1997, p.13).

\subsubsection{Instrumentation}

A self-administered questionnaire consisting of two sections was designed. Section A began with general items querying the respondent's background, experience and qualifications, career experiences, business attempts and most importantly the reasons they left their corporate world into business world. In Section B, the items were eliciting information regarding the motivating or driving factors for venturing into business, their personal and entrepreneurial characteristics, challenges and problems, faced by these corporate women. To obtain the most truthful feedback and to encourage better responses, participants were requested to respond in anonymity.

\subsubsection{Reliability and Validity}

Two of the most important criteria for ensuring an effective measuring instrument are reliability and validity.

Reliability is assessed primarily with statistical indices while validity provides an overall value judgment. The reliability of the instrument was determined using Cronbach Alpha at two points of time, one after the pilot testing and another after the real study. The validity of the instrument was determined using expert judgment upon the items by the supervisor and other experts.

Fourteen respondents participated in a pilot study, while the actual study contained 51 respondents. The Cronbach Alpha for the pilot test as well as the actual study are depicted in the Table 1 below.

\section{<Table 1 about here>}

Looking at the figures for reliability, somewhere between 0.814 to 0.953 , it is safe to assume that the instrument carried good reliability in this study.

Descriptive statistics was used to explore the research questions related to the study. Percentages and medians were used to analyze the data of the study. Descriptive statistics, being significant for describing the data offers a powerful set of 
conceptual tools which one would be able to use in order to extend a better understanding of data in a number of important ways. Median was used in this analysis to obtain central tendency as the data was ordinal and the median can provide good, representative value for this research purpose.

$<$ Table 2 about here>

As shown in Table 2, the techniques chosen to answer the research questions were percentage distribution and the median for Question 1, 2 and 3 while Kruskal Wallis Test was performed to answer Question 4. Based on the analyzed results, reasonable conclusions were drawn and necessary recommendations pertaining to the research problem were made in the following chapters.

\subsection{Data Analysis and Results}

\subsubsection{Profile of the Respondents}

From the 60 sets of questionnaire distributed, 51 sets of answered questionnaires were returned, making the valid number of respondents as 51 . The profile of the respondents is summarized in the following tables.

\section{<Table 3 about here>}

Table 3 above shows the distribution of the respondents according to race. There were 13 Malay respondents (25.5\%), 18 Chinese respondents (35.3\%), and 20 Indian respondents (39.2\%) in this study.

$<$ Table 4 about here $>$

The Table 4 above shows that a major group of the respondents (39.2\%) falls under the 36 to 45 years age group, followed by another $31.4 \%$ respondents falling under the 46 to 55 years age group. About $12 \%$ of the respondents are aged more than 55 years. On the other hand, only $17.7 \%$ of the respondents are aged between 25 and 35 years.

From Table 5 below, it can be seen that many of the respondents (women entrepreneurs) are well educated with 35.3\% holding first degree while another $19.6 \%$ hold post graduate degrees. About $26 \%$ respondents are diploma holders while another $20 \%$ are SPM holders.

$<$ Table 5 about here>

$<$ Table 6 about here $>$

A big group of the respondents (45.1\%) seem to possess working experience less than 10 years.

Table 7 below indicates the last job category of the respondents while they were in corporate sector before becoming women entrepreneurs. About $45 \%$ of the respondents held management posts, while another $41.2 \%$ of them held executive posts. It can also be seen that only about $6 \%$ of the respondents were holding clerical positions.

$<$ Table 7 about here>

$<$ Table 8 about here $>$

As indicated in Table 8 above, about $63 \%$ of respondents were attached to some national organizations prior to becoming entrepreneurs, while another $38 \%$ were in some international organization before they chose to become entrepreneurs.

Table 9 below depicts that majority of the respondents (82.4\%) were initially attached to the private sector. Only $17.6 \%$ respondents were from the public sector prior to moving into own business.

$<$ Table 9 about here $>$

$<$ Table 10 about here $>$

In view of the respondents' attempts into venturing for own business, Table 10 above shows that $82.4 \%$ indicated that this was their first attempt into becoming entrepreneurs while another $15.7 \%$ respondents say that this was their second attempt. Only $2 \%$ say that this was their third attempt to become entrepreneurs.

\section{Research Question 1: What are the factors that spur the corporate women into business ownership?}

The above research question is answered using percentage distribution of the responses and the median (according to the scale 1-5). A number of factors that could have driven or motivated the respondents to become entrepreneurs were presented in the questionnaire and the respondents' responses are presented in percentages in Table 11 below. Among the factors identified to be the main ones and consequently put in sequence are: (1) Need to achieve growth (88.2\%), Personal growth (84.3\%), (2) Job satisfaction (76.5\%), (3) Independence (76.5\%), (4) Flexibility (74.6\%), (5) Autonomy (70.6\%), (6) Presence of business opportunity (64.5\%), (7) Putting passion/knowledge in use (64.5\%), and (8) Economic payoff 
(56.9\%). All these factors were found to fall at the median value of four, indicating the shift of the responses towards the higher side (true and very true) of the scale.

$<$ Table 11 about here>

Family support and co-operation (47.0\%), Recognition (45.1\%), Family commitment (39.2\%), supplement incomes for the family (38.8\%), Balancing career and family (31.3\%) seem to be the motivator factors with a median value of 3 . The next levels of drivers with a median value of 2 are family business (19.6\%) and political and social factors (2.0\%). However, the respondents indicated that Gender discrimination, Relocating of workplace, Traumatic events in their life, Frustration due to block in career advancement, Not fitting into corporate culture, Lack of mentors, and Sexual harassment were not the factors in spurring the women entrepreneurs into business.

\section{Research Question 2: What are the entrepreneurial characteristics of such women?}

Indeed this study also attempts to investigate the entrepreneurial characteristics that these women entrepreneurs possess. The entrepreneur characteristics were studied using two dimensions namely, personal skills and entrepreneur skills. Sixteen personal characteristic variables and twenty five entrepreneurial characteristic variables were examined. In particular, this research question is answered using percentage distribution and the median.

As in Table 12 below, the personal skills that scored a median of 4 and 3 were sequenced so as to provide a better view of the respective skills. Among those skills, Passionate/interest on the business (82.4\% responded as possessing) seem to be the number one skill, followed by listening skills (78.4\%) and communication skills (78.4\%). Hardworking (78.4\%) comes as the fourth ranking skill which is then followed by Perseverance at any situation (66.6\%), Self-management (62.8\%) and Self Discipline (62.7\%) respectively.

$<$ Table 12 about here>

On the other hand, the least possessed skill indicated by these women entrepreneurs are: (1) Being Obsessed, (2) Acquainted networking and collaboration skills, (3) Community service by creating employment and (4) Ability to manage stress.

$<$ Table 13 about here $>$

Twenty five skills identified as entrepreneur skills were laid in the questionnaire for the respondents to indicate the extent of their possession. It is found from Table 13 above that the 10 prime Entrepreneurial Skills that are being indicated as strongly and very strongly possessed by the women entrepreneurs are: (1) Showing confidence, courage and strong will power (78.6\%), (2) Decision-making skills (72.6\%), (3) Leadership skills (66.7\%), (4) Creative thinking in problem solving (64.7\%), (5) Being efficient and effective in executing plans (62.8\%), (6) Leveraging personal accumulation of knowledge, skills and relationship (62.8\%), (7) Entrepreneurial/business knowledge (62.7\%), (8) Being analytical (58.9\%), (9) Balancing skills between personal and business life (58.8\%), and (10) Flexibility- ability to change (58.8\%).

Among the five least possessed entrepreneurial skills identified include (1) computer knowledge (37.2\%), (2) Enhance competitiveness in the market (41.2\%), (3) Risk taking (41.2\%), (4) Good strategic management \& planning practices (43.1\%), and (5) Controlling productive resources and Good marketing strategies (promoting the products) (45.1\%).

\section{Research Question 3: What are the challenges and problems faced by these women entrepreneurs?}

\section{$<$ Table 14 about here $>$}

\section{Findings and Discussion}

A convenience sampling enabled 51 respondents (13 Malay respondents, 18 Chinese respondents, and 20 Indian respondents) to participate in this study. A major group of the respondents were found to be of age above 36 years and only about 18\% respondents were aged between 25 and 35 years. Many of the respondents were well educated with first and post graduate degrees. Less than 30\% respondents were Diploma and SPM holders.

In terms of working experiences, slightly more than a quarter of the respondents possess at least 20 years working experience, with another 32\% having working experience between 10 to 19 years. However, a big portion of the respondents seem to possess working experience less than as relatively unimportant10 years. Most of them reported that they held high management or executive posts prior to becoming women entrepreneurs. With that, the study concluded that prior to setting up their own business; majority of female business owners already had previous work experience 
Further, it is found that more than three quarters of the respondents were initially attached to the private sector as compared to the public sector prior to moving into own business. In terms of their attempts into venturing for own business, many indicated that this was their first attempt.

\section{Conclusion}

This study aimed to explore the phenomenon of corporate women leaving corporate organizations to start their own business. In particular, the following questions were raised. (1) What are the factors that spur women leaving the corporate world into business ownership; (2) What are their personal and entrepreneurial characteristics and (3) What are the challenges and problems they are facing?

Among the factors identified to be the main ones that drove or motivated the respondents to become entrepreneurs are: need to achieve growth, personal growth, job satisfaction, independence, flexibility, autonomy, presence of business opportunity, putting passion/knowledge in use, and economic payoff. However, the respondents indicated that gender discrimination, relocating of workplace, traumatic events in their life, frustration due to block in career advancement, not fitting into corporate culture, lack of mentors, and sexual harassment were not the factors in spurring the women entrepreneurs into business, at least in the Malaysian context.

Indeed this study also attempted to investigate the entrepreneurial characteristics that these women entrepreneurs possess. The entrepreneur characteristics were studied using two dimensions namely, personal skills and entrepreneur skills. Sixteen personal characteristic variables and twenty five entrepreneurial characteristic variables were examined. The personal skills strongly possessed by the respondents were identified to be passionate/interest on the business, listening skills, and communication skills, hardworking, and perseverance at any situation, self-management, and self discipline.

Among the ten prime entrepreneurial skills strongly possessed by the women entrepreneurs are: showing confidence, courage and strong will power, decision-making skills, leadership skills, creative thinking in problem solving, being efficient and effective in executing plans, leveraging personal accumulation of knowledge, skills and relationship, entrepreneurial/business knowledge, being analytical, balancing skills between personal and business life, and flexibility respectively. However, the five least possessed entrepreneurial skills include computer knowledge; enhance competitiveness in the market, risk taking, good strategic management \& planning practices, controlling productive resources and good marketing strategies.

The question of challenges/problems faced by these women entrepreneurs found some evidences in the form of shortage of professional staffs, shortage of staffs, issues of development and growth, shortage of committed/sincere staffs, low management practices/systems, financial constraint due to heavy overheads, lack of start-up capital, isolation of taking decision alone, shouldering heavy workloads, and less consultation help from experts. At the same time, the list of least challenges/problems encountered by the respondents unveils the following: engagement in too many businesses, unattractive remuneration package, and lack of support from business partners, lack of family support, shortage of peer support due to family commitment.

\section{Recommendation For Future Researchers}

Based on the findings of this research, the following suggestions are forwarded to future researchers.

(i) A rigorous research comprising bigger sample is recommended.

(ii) A study with much wider scope might be able to furnish more details on the entrepreneurial nature for women.

(iii) A qualitative study or a mixed mode might be necessary to find out more accurately the exact challenges and problems these women entrepreneurs are facing.

\section{Concluding comments}

The study demonstrated that corporate women entrepreneurs did not enter the business world due to family commitment but rather due to personal achievement, independency and autonomy which seems to be parallel with the pull factors theory.

The findings provide new insight on the personal and entrepreneurial characteristic of corporate women entrepreneurs marching into business ownership. Passionate in their desired business, showing courage, confident and strong will power were their strongest skills. It is also evident from this research that corporate women entrepreneurs use their vast working experiences and inherent strength to overcome many shortcomings and hurdles along the path confidentially to pursuit their dreams. 
Due to the limited number of variables on the questionnaire, it would be presumptuous to conclude that the study's findings can adequately explain the major challenges and problems faced by corporate women entrepreneurs are inadequate professional manpower. To make reasonable conclusions, more data is required. Hence, it is recommended that additional issues to be raised by the future researchers.

There are various debates over the past decade on the performance of women entrepreneurs, management practices, successful women entrepreneurs, networks among women entrepreneurs. However, very little research was done on corporate women making a leap business ownership in Malaysia. As such, the collection of data on the profile, working experience, education, management skill, sector, personal and entrepreneurial characteristics and the factors that spur corporate women into entrepreneurs and challenges and problems faced by them. These allow policy makers and women associations to identify the reasons women leaving the corporate world in order to nurture and support these women from a pitfall. Without these supports, the efforts in creating quality, resilient and successful women entrepreneurs in all sectors of the economy would be cumbersome. Providing a strong support, Malaysian women entrepreneurs will maximize their full potential which empowers their contribution to the country and global economy.

The benefits of networking will engage these women entrepreneurs in entrepreneurial activities such as scanning for, recognizing and exploiting business opportunities. These corporate women geared themselves with management, and financial skills that are deemed to be important for business success. However, these women need to have an acute understanding of the entrepreneurial orientation in order for them to succeed in their ventures. These orientations included risk taking, creativity and innovativeness, man power, problem solving skills; multi-tasking and so on can be embedded within the women entrepreneurs through workshops, training programmes, mentoring or self-advancement courses. This is women business associations take the role in nurturing these skills within these women entrepreneurs could help to mould successful women entrepreneurs. In line with this, the researcher would like future researchers to investigate on how effective women business associations playing their roles in reaching out to women entrepreneurs.

One thing is for sure. The women business associations and the government of Malaysia can no longer ignore the burgeoning power of women in our economy. Encouraging that realization and helping it take root sooner rather than later must be the major goal for our government.

\section{References}

Aminah, A. (1998). Women in Malaysia. Retrieved April 20, 2006, from http://www.adb.org/Documents/Books/Country_Briefing_Papers/Women_in_Malaysia/women_malaysia.pdf

Amzad H, (2009). Factors Influencing Women Business Development in the Developing Countries: Evidence from Bangladesh, International Journal of Organizational Analysis Vol. 17 No. 3, pp. 202-224, Emerald Group Publishing Limited. doi:10.1108/19348830910974923, http://dx.doi.org/10.1108/19348830910974923

Bitange N, Fides W M (2007). Women Entrepreneurs and Strategic Decision Making, Management Decision. Vol. 45, 1, (pp. 118-130). Emerald Group Publishing Limited.

Gartner, William B. 1989. "Who is an Entrepreneur?" Is the Wrong Question." Entrepreneurial Theory and Practice 13 (Summer):47-68.

Global Entrepreneurship Monitor (GEM) (2004). Women and Entrepreneurship. Center for Women's Leadership. Banson College. MA, USA.

Helms. M. (1997) Women and Entrepreneurship: The Appealing Alternative. Business Perspectives. Vol. 10, 11 (pp. 16-19). Gale Group - Information Integrity.

Jamilah, A. (1992). Women \& Development in Malaysia. Kuala Lumpur: Pelanduk Publications (M) Sdn. Bhd.

Julie R. Weeks. (2009) Women business owners in the Middle East and North Africa: A Five-Country Research Study, International Journal of Gender and Entrepreneurship, Vol. 1 No. 1, 2009, pp. 77-85, Emerald Group Publishing Limited, doi:10.1108/17566260910942354, http://dx.doi.org/10.1108/17566260910942354

Kamal N, Wojoud R, Rana N, 2009, Factors that Affect Women Entrepreneurs: Evidence from an Emerging Economy, International Journal of Organizational Analysis Vol. 17 No. 3, pp. 225-247, Emerald Group Publishing Limited, doi:10.1108/19348830910974932, http://dx.doi.org/10.1108/19348830910974932

Kim K, (2007), Shifting Family Involvement During the Entrepreneurial Process, International Journal of Entrepreneurial Behaviour \& Research Vol. 13 No. 5, (pp. 258-117). Emerald Group Publishing Limited. doi:10.1108/13552550710780867, http://dx.doi.org/10.1108/13552550710780867 
Md. Nor Othman, Ezlika Ghazali, and Ong Chee Cheng (2004), Demographic and Personal Characteristics of Urban Malaysian Entrepreneurs: An Ethnic Comparison , in the Third International Conference on SMEs in a Global Economy Conference Proceedings, eds. Adnan A., Ismail A.W., and Za faran H., Shah Alam: Universiti Teknologi MARA and University of Wollongong, Australia, 509-529.

Moore, D.P. \& Buttner, E.H. (1997). Women entrepreneurs: Moving beyond the glass ceiling. Thousand Oaks, CA: Sage Publications, Inc. (262 pp)

Women in Management (Nov 1997), Final Management Report by Carina Yau

Women's Aid Organisation (WAO). (2001).Women's Equality in Malaysia Status Report. Retrieved June 7, 2008, from http://www.wao.org.my/news/20010301statusreport.htm

Table 1 . Reliability of the instrument

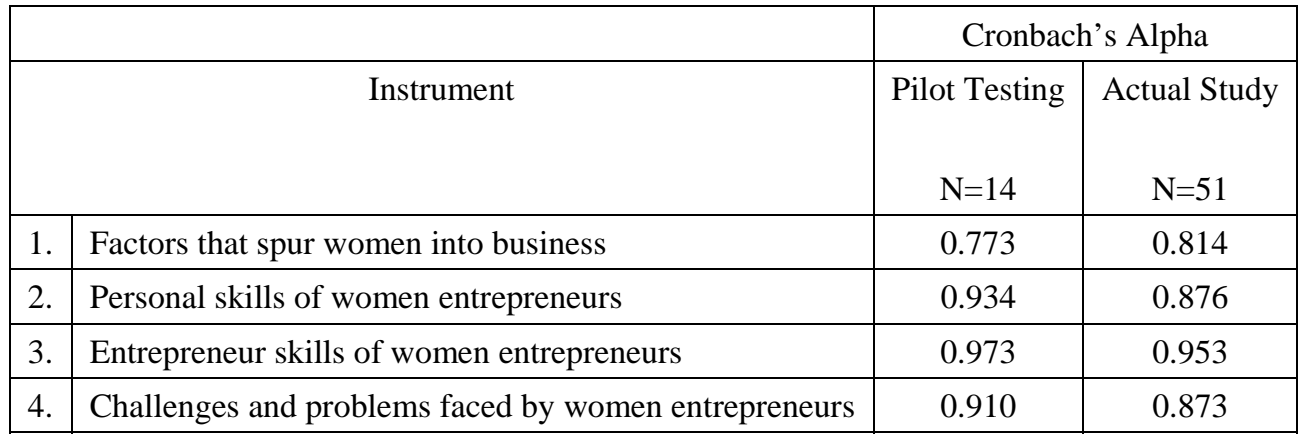

Table 2. Statistic Analysis Employed

\begin{tabular}{|l|l|}
\hline Research Questions & Statistical Analysis employed \\
\hline $\begin{array}{l}\text { (1) What are the factors that spur women from leaving the } \\
\text { corporate world into business ownership? }\end{array}$ & $\begin{array}{l}\text { Percentage distribution of factors and their } \\
\text { Median }\end{array}$ \\
\hline (2) What are their personal and entrepreneurial characteristics? & $\begin{array}{l}\text { Percentage distribution of characteristics and } \\
\text { their Median }\end{array}$ \\
\hline (3) What are the challenges and problems they are facing, and & $\begin{array}{l}\text { Percentage distribution of } \\
\text { challenges/problems and their Median }\end{array}$ \\
\hline
\end{tabular}

Table 3: Respondents according to Race

\begin{tabular}{|l|l|l|}
\hline Race & No. of Respondents & Percentage \\
\hline Malay & 13 & 25.5 \\
\hline Chinese & 18 & 35.3 \\
\hline Indian & 20 & 39.2 \\
\hline Total & & 100 \\
\hline
\end{tabular}

Table 4. Respondents according to Age Group

\begin{tabular}{|l|l|l|}
\hline Age Group & No. of Respondent & Percentage \\
\hline 25 yrs and below & 1 & 2.0 \\
\hline $26-35$ yrs & 8 & 15.7 \\
\hline $36-45$ yrs & 20 & 39.2 \\
\hline $46-55$ yrs & 16 & 31.4 \\
\hline Above 55 yrs & 6 & 11.8 \\
\hline Total & & 100 \\
\hline
\end{tabular}


Table 5. Respondents according to Highest Academic Qualification

\begin{tabular}{|l|l|l|}
\hline Highest Academic Qualification & No. of Respondent & Percentage \\
\hline Masters/PhD & 10 & 19.6 \\
\hline First Degree & 18 & 35.3 \\
\hline Diploma & 13 & 25.5 \\
\hline SPM & 10 & 19.6 \\
\hline Total & & 100 \\
\hline
\end{tabular}

Table 6. Respondents according to Working Experience

\begin{tabular}{|l|l|l|}
\hline Working Experience & No. of Respondent & Percentage \\
\hline More than 20 yrs & 12 & 23.5 \\
\hline $15-19$ yrs & 8 & 15.7 \\
\hline $10-14$ yrs & 8 & 15.7 \\
\hline Less than 10 yrs & 23 & 45.1 \\
\hline Total & & 100.0 \\
\hline
\end{tabular}

Table 7. Respondents according to Last Job Category

\begin{tabular}{|l|l|l|}
\hline Last Job Category & No. of Respondent & Percentage \\
\hline Clerical level & 3 & 5.9 \\
\hline Executive level & 21 & 41.2 \\
\hline Management level & 23 & 45.1 \\
\hline Corporate level & 4 & 7.8 \\
\hline Total & 51 & 100.0 \\
\hline
\end{tabular}

Table 8. Respondents according to Type of Former Organization

\begin{tabular}{|l|l|l|}
\hline Type of Former Organization & No. of Respondents & Percentage \\
\hline International & 19 & 37.3 \\
\hline National & 32 & 62.7 \\
\hline Total & & 100.0 \\
\hline
\end{tabular}

Table 9. Respondents according Type of Sector they were attached before

\begin{tabular}{|l|l|l|}
\hline Type of Sector & No. of Respondents & Percentage \\
\hline Private & 42 & 82.4 \\
\hline Public & 9 & 17.6 \\
\hline Total & 51 & 100.0 \\
\hline
\end{tabular}

Table 10. Respondents and their Attempts into own business

\begin{tabular}{|l|l|l|}
\hline Attempts & No. of Respondents & Percentage \\
\hline First Attempt & 42 & 82.4 \\
\hline Second Attempt & 8 & 15.7 \\
\hline Third Attempt & 1 & 2.0 \\
\hline Total & 51 & 100.0 \\
\hline
\end{tabular}


Table 11. Percentage Distribution of the Responses regarding the Drive towards Entrepreneurship

\begin{tabular}{|c|c|c|c|c|c|c|c|}
\hline $\begin{array}{l}\mathrm{N} \\
\mathrm{O}\end{array}$ & ITEM & $\begin{array}{l}\text { Not True } \\
\text { at all } \\
\text { (\%) }\end{array}$ & $\begin{array}{l}\text { Least } \\
\text { True } \\
(\%)\end{array}$ & $\begin{array}{l}\text { Some-w } \\
\text { hat True } \\
\text { (\%) }\end{array}$ & $\begin{array}{l}\text { Quite } \\
\text { True } \\
(\%)\end{array}$ & $\begin{array}{l}\text { Very } \\
\text { True } \\
(\%)\end{array}$ & $\begin{array}{l}\text { Me } \\
\text { dian }\end{array}$ \\
\hline & $\begin{array}{l}\text { motivator or drive to make a leap into business has been: } \\
\text { (a) the need to achieve personal growth }\end{array}$ & - & 2.0 & 13.7 & 43.1 & 41.2 & 4 \\
\hline & (b) recognition & 5.9 & 25.5 & 23.5 & 29.4 & 15.7 & 3 \\
\hline & (c) job satisfaction (sense of self-worth) & 2.0 & 2.0 & 19.6 & 39.2 & 37.3 & 4 \\
\hline & (d) economic payoff & - & 11.9 & 31.4 & 35.3 & 21.6 & 4 \\
\hline & (e) independency & - & 3.9 & 19.6 & 41.2 & 35.3 & 4 \\
\hline & (f) the need to freedom and flexibility & 2.0 & 2.0 & 21.6 & 37.3 & 37.3 & 4 \\
\hline & (g) family business. & 41.2 & 19.6 & 19.6 & 13.7 & 5.9 & 2 \\
\hline & (h) family commitments. & 15.7 & 13.7 & 31.4 & 15.7 & 23.5 & 3 \\
\hline & (i) balancing career and family. & 9.8 & 11.8 & 21.6 & 33.3 & 23.5 & 4 \\
\hline & (j) create supplement incomes for the family. & 9.8 & 21.6 & 29.4 & 31.4 & 7.8 & 3 \\
\hline & (k) gender discrimination at work-place. & 51.0 & 31.4 & 3.9 & 7.8 & 5.9 & 1 \\
\hline & (l) presence of business opportunity. & 2.0 & 7.8 & 27.5 & 35.3 & 29.2 & 4 \\
\hline & (m) desire/passion to put knowledge and skills into use. & - & 2.0 & 23.5 & 35.3 & 29.2 & 4 \\
\hline & (n) personal achievement (interest). & - & 3.9 & 7.8 & 43.1 & 45.1 & 4 \\
\hline & (o) autonomy (freedom). & 3.0 & 3.9 & 21.6 & 47.1 & 23.5 & 4 \\
\hline & $\begin{array}{l}\text { (p) the demand of relocating of an executive position or } \\
\text { husband position. }\end{array}$ & 56.9 & 23.5 & 9.8 & 9.8 & 2.0 & 1 \\
\hline & (q) organizational dynamics dealt with power and politics. & 41.2 & 31.4 & 27.5 & - & - & 1 \\
\hline & (r) social and political factor in the country & 37.3 & 35.3 & 25.5 & 2.0 & - & 2 \\
\hline & (s) traumatic events- eg. divorcee, widower & 66.7 & 15.7 & 17.6 & - & - & 1 \\
\hline 2. & $\begin{array}{l}\text { I started business out of frustration due to blocks to } \\
\text { corporate advancement (Lack of career advancement and } \\
\text { discrimination). }\end{array}$ & 56.9 & 13.7 & 15.7 & 7.8 & 5.9 & 1 \\
\hline 3. & $\begin{array}{l}\text { I started business due to lack of mentors or role models in } \\
\text { my earlier organization. }\end{array}$ & 62.7 & 17.6 & 7.8 & 5.9 & 5.9 & 1 \\
\hline 4. & $\begin{array}{l}\text { I started business because I felt of not fitting into a } \\
\text { corporate culture. }\end{array}$ & 52.9 & 27.5 & 5.9 & 7.8 & 5.9 & 1 \\
\hline 5. & $\begin{array}{l}\text { I started business because I get family support and } \\
\text { co-operation. }\end{array}$ & 23.5 & 7.8 & 21.6 & 17.6 & 29.4 & 3 \\
\hline 6. & $\begin{array}{l}\text { I started business because I find it difficult to balance } \\
\text { career and family. }\end{array}$ & 31.4 & 17.6 & 19.6 & 13.7 & 17.6 & 3 \\
\hline 7. & $\begin{array}{l}\text { I started business because of sexual harassments at the } \\
\text { workplace. }\end{array}$ & 84.3 & 9.8 & 2.0 & 2.0 & 2.0 & 1 \\
\hline
\end{tabular}


Table 12. Percentage distribution of Personal Skills possessed by respondents

\begin{tabular}{|c|c|c|c|c|c|c|c|}
\hline No. & Item & $\begin{array}{c}\text { Not } \\
\text { At All } \\
(\%)\end{array}$ & $\begin{array}{c}\text { Least } \\
\text { Possess } \\
(\%)\end{array}$ & $\begin{array}{c}\text { Some-what } \\
\text { Possess } \\
(\%)\end{array}$ & $\begin{array}{c}\text { Strongly } \\
\text { Possess } \\
(\%)\end{array}$ & $\begin{array}{c}\text { Very } \\
\text { Strongly } \\
\text { Possess } \\
(\%)\end{array}$ & Median \\
\hline 5. & Passionate/interest on the business & - & - & 17.6 & 41.2 & 41.2 & 4 \\
\hline 3. & Listening skills & - & - & 21.6 & 52.9 & 25.5 & 4 \\
\hline 4. & Communication skills & - & 2.0 & 19.6 & 52.9 & 25.5 & 4 \\
\hline 16. & Hardworking & 2.0 & 7.8 & 11.8 & 49.0 & 29.4 & 4 \\
\hline 8. & Perseverance at any situation & 2.0 & 2.0 & 29.4 & 49.0 & 17.6 & 4 \\
\hline 10. & Self-management & 2.0 & 2.0 & 33.3 & 51.0 & 11.8 & 4 \\
\hline 13. & Self-discipline & - & 3.9 & 33.3 & 45.1 & 17.6 & 4 \\
\hline 1. & Proactive personality & - & 7.8 & 29.4 & 39.2 & 23.5 & 4 \\
\hline 2. & Set goals and action plan & - & 2.0 & 35.3 & 45.1 & 17.6 & 4 \\
\hline 6. & Persistent & 2.0 & 3.9 & 31.4 & 43.1 & 19.6 & 4 \\
\hline 9. & Good time management & 5.9 & 3.9 & 33.3 & 49.0 & 7.8 & 4 \\
\hline 11. & Good Instinct & 2.0 & 3.9 & 39.2 & 43.1 & 11.8 & 4 \\
\hline 14. & Able to managing stress & - & 9.8 & 41.2 & 33.3 & 15.7 & 3 \\
\hline 15 & $\begin{array}{l}\text { Community service by creating } \\
\text { employment }\end{array}$ & 5.9 & 7.8 & 31.2 & 37.3 & 9.8 & 3 \\
\hline 12. & $\begin{array}{l}\text { Acquainted networking and } \\
\text { collaboration skills }\end{array}$ & - & 7.8 & 45.1 & 33.3 & 13.7 & 3 \\
\hline 7. & Obsessed & 15.7 & 15.7 & 41.2 & 17.6 & 9.8 & 3 \\
\hline
\end{tabular}

Table 13. Percentage distribution of Entrepreneurial Skills possessed by respondents

\begin{tabular}{|l|l|c|c|c|c|c|c|}
\hline $\begin{array}{c}\text { Item } \\
\text { No. }\end{array}$ & \multicolumn{1}{|c|}{ Entrepreneurial skills } & $\begin{array}{c}\text { Not at } \\
\text { all } \\
(\%)\end{array}$ & $\begin{array}{c}\text { Least } \\
\text { Possess } \\
(\%)\end{array}$ & $\begin{array}{c}\text { Some-wh } \\
\text { at Possess } \\
(\%)\end{array}$ & $\begin{array}{c}\text { Strongly } \\
\text { Possess } \\
(\%)\end{array}$ & $\begin{array}{c}\text { Very } \\
\text { Strongly } \\
\text { Possess } \\
(\%)\end{array}$ & $\begin{array}{c}\text { Med } \\
\text {-ian }\end{array}$ \\
\hline 6. & $\begin{array}{l}\text { Showing confidence, courage and strong } \\
\text { will power. }\end{array}$ & - & - & 21.6 & 45.3 & 33.3 & 4 \\
\hline 15. & Coordinating business development & 2.0 & 3.9 & 39.2 & 39.2 & 15.7 & 4 \\
\hline 13. & Decision-making skills. & - & - & 27.5 & 41.2 & 31.4 & 4 \\
\hline 16. & Leadership skills & - & - & 33.3 & 41.2 & 25.5 & 4 \\
\hline 22. & Creative thinking in problem solving & 2.0 & 2.0 & 31.4 & 47.1 & 17.6 & 4 \\
\hline 7. & $\begin{array}{l}\text { Being efficient and effective in executing } \\
\text { plans. }\end{array}$ & - & 2.0 & 35.3 & 37.3 & 25.5 & 4 \\
\hline 4. & $\begin{array}{l}\text { Leveraging personal accumulation of } \\
\text { knowledge, skills and relationship. }\end{array}$ & 2.0 & 2.0 & 33.3 & 47.1 & 15.7 & 4 \\
\hline 1. & $\begin{array}{l}\text { Entrepreneurial/business knowledge } \\
\text { (products/services) }\end{array}$ & 2.0 & 3.9 & 31.4 & 39.2 & 23.5 & 4 \\
\hline 5. & Being analytical. & - & 2.0 & 39.2 & 47.1 & 11.8 & 4 \\
\hline 23. & $\begin{array}{l}\text { Balancing skills between personal and } \\
\text { business life }\end{array}$ & - & - & 41.2 & 43.1 & 15.7 & 4 \\
\hline 24. & Flexibility- adapt to changes & - & 3.9 & 37.3 & 41.2 & 17.6 & 4 \\
\hline 11. & $\begin{array}{l}\text { Efficient in producing high quality } \\
\text { product/services. }\end{array}$ & 2.0 & 5.9 & 37.3 & 43.1 & 11.8 & 4 \\
\hline 12. & Delegation of job responsibilities to staff. & 2.0 & 5.9 & 37.3 & 39.2 & 15.7 & 4 \\
\hline 14. & $\begin{array}{l}\text { HR Management (recruiting, training and } \\
\text { managing staffs) }\end{array}$ & 2.0 & 7.8 & 35.3 & 37.3 & 17.6 & 4 \\
\hline 18. & $\begin{array}{l}\text { Team building \& conducting meetings } \\
\text { ability }\end{array}$ & - & 3.9 & 43.1 & 37.3 & 15.7 & 4 \\
\hline 19. & Creativity (venturesome) and systematic & 2.0 & 9.8 & 39.2 & 35.3 & 13.7 & 3 \\
\hline & & & & & & 4 \\
\hline
\end{tabular}




\begin{tabular}{|l|l|c|c|c|c|c|c|}
\hline 20. & $\begin{array}{l}\text { Financial Management - to manage } \\
\text { monthly cash-flow }\end{array}$ & 2.0 & 11.8 & 37.3 & 29.4 & 19.6 & 3 \\
\hline 21. & Innovative behaviors & 2.0 & 5.9 & 43.1 & 41.2 & 7.8 & 3 \\
\hline 17. & Policy development and execution skills & - & 3.9 & 49.0 & 31.4 & 15.7 & 3 \\
\hline 9. & $\begin{array}{l}\text { Good marketing strategies (promoting } \\
\text { the products). }\end{array}$ & 3.9 & 7.8 & 43.1 & 29.4 & 15.7 & 3 \\
\hline 2. & Controlling productive resources & 5.9 & 5.9 & 43.1 & 37.3 & 7.8 & 3 \\
\hline 8. & $\begin{array}{l}\text { Good strategic management \& planning } \\
\text { practices. }\end{array}$ & 2.0 & 9.8 & 45.1 & 25.5 & 17.6 & 3 \\
\hline 3. & Risk taking & 5.9 & 7.8 & 45.1 & 27.5 & 13.7 & 3 \\
\hline 25 & Enhance competitiveness in the market & 2.0 & 3.9 & 52.9 & 31.4 & 9.8 & 3 \\
\hline 10. & Computer knowledge. & 3.9 & 9.8 & 49.0 & 29.4 & 7.8 & 3 \\
\hline
\end{tabular}

Table 14. Percentage distribution of Challenges/Problems faced by Respondents

\begin{tabular}{|l|l|c|c|c|c|c|c|}
\hline No. & \multicolumn{1}{|c|}{ Item } & $\begin{array}{c}\text { Not } \\
\text { at all }\end{array}$ & $\begin{array}{c}\text { Least } \\
\text { Possess }\end{array}$ & $\begin{array}{c}\text { Some- } \\
\text { what } \\
\text { Possess } \\
(\%)\end{array}$ & $\begin{array}{c}\text { Strongly } \\
\text { Possess }\end{array}$ & $\begin{array}{c}\text { Very } \\
\text { Strongly } \\
\text { Possess } \\
(\%)\end{array}$ & $\begin{array}{c}\text { Medi } \\
- \text {-an }\end{array}$ \\
$(\%)$
\end{tabular}

